\title{
DECENTRALISATIE VAN DE FINANCIERINGSBESLISSING IN MULTINATIONALE GEDIVERSIFICEERDE ONDERNEMINGEN
}

\author{
door Dr. J. H. W. Goslings
}

\section{Bouwstenen van de studie}

Het belangrijkste uitgangspunt voor dit proefschrift ${ }^{1}$ ) is de veronderstelling van welvaartsmaximalisatie voor de aandeelhouders. Hiervan zijn vermogenskosten afgeleid die de volgende eigenschappen hebben:

- vermogenskosten zijn binnen een ruim gebied onafhankelijk van de door de onderneming toegepaste mate van hefboomwerking,

- vermogenskosten worden in hoge mate bepaald door het bedrijfsrisiko, dat naar voren komt in een industrieklassifikatie. Deze konklusie geldt niet alleen wanneer één land beschouwd wordt, maar ook als de analyse wordt uitgebreid tot meerdere landen. In het laatste geval is de konklusie minder hard en moet tenminste aan de eis voldaan zijn dat er relatief sterke ekonomische relaties tussen de beschouwde landen bestaan.

Deze konklusies worden in belangrijke mate bevestigd door beschikbaar empirisch onderzoek.

Aan deze uitkomsten wordt een organisatorische variabele toegevoegd. Uit de resultaten van het onderzoek naar het menselijk gedrag binnen de organisatie blijkt, dat decentralisatie in algemene zin samengaat met een verhoogd ekonomisch prestatieniveau. Een praktische uitvoering van decentralisatie, waarbij tegelijkertijd koördinatie en hiërarchische struktuur gehandhaafd blijven, wordt gevonden in elkaar meervoudig overlappende groepen. Funktionarissen die in meerdere groepen zijn opgenomen vervullen een ,linking pin" funktie. Op deze organisatiestruktuur wordt een beroep gedaan, indien de kwantitatieve voordelen van centralisatie niet opwegen tegen de organisatorische voordelen van decentralisatie.

\section{Uitwerking binnen een land}

De onafhankelijkheid van vermogenskosten van de financieringsstruktuur maakt het mogelijk de investeringsbeslissing los van de vermogensvoorziening te behandelen. Alleen globaal, via een budgettering, zijn beide terreinen in de besluitvorming met elkaar verbonden. Investeringsbeslissingen kunnen daarom naar produkt-divisie gedecentraliseerd worden als de beslissing de vermogenskosten niet verandert. Dit is het geval voor marktpenetratie, doch geldt slechts gedeeltelijk voor produkt- en marktontwikkeling. In de laatste twee gevallen is een zekere mate van centralisatie vereist. Diversifikatie leidt altijd tot een gecentraliseerde beslissing.

Aan de gedecentraliseerde investeringsbeslissing is een gecentraliseerde kontrole toegevoegd. De kontrole dient aan te sluiten bij de oorspronkelijke investeringsbeslissing. Hiertoe is het nodig een afschrijvingssysteem te kiezen, dat dicht aansluit bij ,economic depreciation". Bij een verwachting van konstante kasstromen valt de annuïteitenmethode samen met de ekonomi-

1) Eind 1975 verschijnt een handelseditie uitgegeven door Stenfert Kroese. 
konstante kasstromen valt de annuïteitenmethode samen met de ekonomische afschrijvingen. Het resultaat kan vervolgens vergeleken worden met de vermogenskosten. Door dit resultaat te presenteren volgens een „residual income" methode, worden een aantal nadelen van de R.O.I.-presentatie vermeden. Hoewel niet kritisch voor de kontrole, kan het toch wenselijk zijn de investeringsbasis en daarmee de afschrijvingen van tijd tot tijd bij te stellen op basis van de werkelijke ekonomische waarde. Een geschikt moment is een definitieve verandering in de verwachtingen. Een dergelijke bijstelling kan gereflekteerd worden in de gepubliceerde cijfers en voorkomt extreme inkomensresiduen over langere perioden.

De vermogensvoorziening, alleen betrokken op vreemd vermogen, staat in hoge mate los van de investeringsbeslissing binnen de werkmaatschappijen. Hefboomwerking heeft immers geen of nauwelijks invloed op de vermogenskosten, zodat alleen de beschikbaarheid van vermogen binnen de gebudgetteerde normen van belang is. Minimalisatie van de rentekosten staat voorop bij de te kiezen organisatievorm. In de minimalisatie van de kosten wordt tevens de enige methode gevonden om de vermogenskosten, ceteris paribus, voor de onderneming te verlagen. Kostenbesparingen worden gevonden in schaaleffekten en superieure timing. Beide dwingen tot centralisatie.

\section{Uitwerking bij meerdere landen}

De invloed van meerdere landen op de vermogenskosten is twijfelachtig. Er lijkt reden te bestaan om aan te nemen dat binnen landen met nauwe ekonomische kontakten vermogenskosten voor gelijke risiko's gelijk zijn. Dit leidt tot uniforme vermogenskosten voor gelijke industrieën. Binnen deze landen is decentralisatie van de investeringsbeslissing naar divisies onverminderd mogelijk en is koördinatie naar land relatief onbelangrijk. Koördinatie naar land en centralisatie worden belangrijker als landen ekonomisch minder verbonden zijn en de vermogenskosten uiteen gaan lopen.

De kontrole in de multinationale onderneming wordt geheel beheerst door de mogelijkheid om de resultaten op een ekonomisch interpreteerbare wijze te vertalen. Zijn koersveranderingen ongeanticipeerd, dan leidt vertaling tegen de lopende koers tot een juiste „economic value” in de binnenlandse valuta. Dit maakt het theoretisch mogelijk de buitenlandse resultaten na vertaling te beoordelen. Zijn koersveranderingen geanticipeerd, dan bestaat er geen eenvoudige of plausibele vertaalmethode, waardoor het te prefereren is om kontrole in de buitenlandse valuta te laten plaatsvinden.

In de organisatie van de leningvoorziening is een onderscheid gemaakt tussen het aantrekken van langlopende en kortlopende leningen. Voor kortlopende leningen worden als belangrijke krachten tot decentralisatie gesignaleerd: verhoogde slagvaardigheid en betere lokale kennis, zowel omtrent de vermogensbehoefte alsook omtrent de financieringsmogelijkheden. Op langere termijn gelden deze krachten niet. Centralisatie is echter niet in die mate mogelijk als dit binnen één land bepleit werd. De oorzaak hiervan is te vinden in de belangrijke rol die langlopende leningen spelen in het afdekken van valutarisiko's. Omdat het valutarisiko nauw verbonden is met de lopende bedrijfsbeslissingen is een zekere mate van koördinatie met de divisies gewenst.

ma $a$ blz. 248 